\title{
AL-IDARAH:
}

JURNAL PENGKAJIAN DAKWAH DAN MANAJEMEN

ISSN-E : 2654-4407 | ISSN-P : 2337-5035

http://jurnal.uinsu.ac.id/index.php/idarah/index

Vol. 9 No. 2 Juli-Desember 2021, hlm. 1-10

\section{Model Manajemen Bencana Berbasis Pemberdayaan Masyarakat}

\author{
Herdi \\ Universitas Muslim Nusantara Alwashliyah Medan, Medan, Indonesia \\ Email korespondeni: herdiramon@gmail.com
}

\begin{abstract}
ABSTRAK
Secara geografis Indonesia terletak di daerah katulistiwa dengan morfologi yang beragam dari dataran sampai pegunungan tinggi. Hal ini menyebabkan Indonesia telah mengalami berbagai bencana yang menyebabkan kerugian jiwa dan materi yang besar yang akan terus berulang kejadiannya. Peta potensi bencana gempa di Indonesia menunjukkan bahwa Indonesia adalah wilayah dengan zona-zona gempa yang rawan, peta potensi bencana tanah longsor, peta potensi bencana letusan gunungapi, peta potensi bencana tsunami, peta potensi bencana banjir, dan lain-lain. Potensi bencana akibat kenaikan permukaan laut terhadap kondisi lingkungan bio-geofisik yang berantai yaitu dengan meningkatnya frekuensi dan intensitas banjir maka terjadi perubahan arus laut dan meluasnya kerusakan mangrove, akibatnya akan meluas pula intrusi air laut yang mengancam kegiatan sosialekonomi masyarakat pesisir, serta berkurangnya luas daratan atau hilangnya pulau-pulau kecil. Upaya strategis untuk melindungi setiap warga negara dengan langkah-langkah penanggulangan bencana (manajemen bencana) baik sebelum, pada saat dan setelah bencana. Di samping itu, upaya pemberdayaaan komunitas agar memiliki informasi memadai, waspada, lebih aktif, serta memiliki kemampuan untuk berkoordinasi dan mendukung pemerintah dalam kegiatan prevensi maupun mitigasi. Komunitas lokal dapat memberikan dukungan dalam bentuk informasi, usulan maupun gagasan kepada pemerintah, bahkan sumber daya tertentu yang tidak dapat disediakan oleh pemerintah. Melibatkan komunitas dalam perencanaan manajemen bencana dan mendorong komunitas berpartisipasi akan memberikan nilai tambah.
\end{abstract}

Kata Kunci: Model Manajemen Bencana; Pemberdayaan Masyarakat 


\section{PENDAHULUAN}

Secara geografis Indonesia terletak di daerah katulistiwa dengan morfologi yang beragam dari dataran sampai pegunungan tinggi. Keragaman morfologi ini dipengaruhi oleh faktor geologi terutama dengan adanya aktivitas pergerakan lempeng tektonik aktif di sekitar perairan Indonesia (Lempeng Eurasia, Hindia-Australia, dan lempeng dasar Samudera Pasifik). Pergerakan lempeng-lempeng tersebut menyebabkan terbentuknya jalur gempa bumi, rangkaian gunung api aktif serta patahan-patahan geologi yang merupakan zone rawan bencana gempa bumi dan tanah longsor.

Dari beberapa fakta dan data yang ada, Indonesia telah mengalami berbagai bencana yang menyebabkan kerugian jiwa dan materi yang besar yang akan terus berulang kejadiannya (lihat tabel. 1 di bawah). Tatanan geologi dan tektonik Indonesia membentuk jalur gempa dan jalur gunungapi dengan ribuan titik pusat gempa dan ratusan gunung api yang pernah dan terus berpotensi untuk menjadi ancaman. Gerakan seismik yang kemudian menimbulkan gempa tektonik disebabkan oleh pergeseran di dalam perut bumi. Pusat gempa dangkal $(0-85 \mathrm{~km})$ dan kedalaman sedang $(185-300 \mathrm{~km})$ banyak terdapat di Pulau Sumatra, Jawa, Nusa Tenggara, Sulawesi, Maluku, dan Irian Jaya. Pusat gempa yang dalam terdapat di Pulau Sumatera dan Jawa. Di berbagai daerah pantai, gempa bumi kerap kali diikuti tsunami seperti yang terjadi di Flores (1992), Biak (1996), Aceh (2004), dan Pangandaran (2007) yang mengakibatkan banyaknya korban jiwa dan kerusakan harta benda.

Tabel. 1. Kejadian Bencana di Indonesia Tahun 2004 dan 2005

\begin{tabular}{|l|c|c|c|c|}
\hline \multicolumn{1}{|l|}{ LOKASI } & \multicolumn{2}{l|}{ 2018 } & \multicolumn{2}{l|}{} \\
\cline { 2 - 5 } BENCANA & Kab/Kota & Provinsi & Kab/Kota & Provinsi \\
\hline Banjir & 13 & 8 & 16 & 10 \\
\hline Gempa Bumi & 9 & 7 & 12 & 5 \\
\hline Gempa Bumi \& Tsunami & 14 & 2 & & \\
\hline Tanah Longsor & & & 9 & 6 \\
\hline Banjir Bandang & 13 & 6 & 1 & 1 \\
\hline Letusan Vulkanik & 3 & 2 & 1 & 1 \\
\hline
\end{tabular}




\begin{tabular}{|l|l|l|l|l|}
\hline Badai & 5 & 4 & & \\
\hline
\end{tabular}

Rangkaian gunungapi membentang dari Pulau Sumatera, Jawa, Bali, Nusa Tenggara, Kepulauan di laut Banda, dan Pulau Sulawesi yang merupakan daerah gunung api terpanjang di dunia yang sejak dulu menjadi ancaman yang sewaktu-waktu terjadi. Di Indonesia terdapat 129 gunungapi aktif, 70 buah di antaranya menjadi ancaman dan ada 500 buah tidak aktif, sebagian penduduk tinggal di sekitar daerah ancaman gunungapi ini. Karakter klimatologi dan meteorologi Indonesia menimbulkan pertukaran musim yang diwarnai depresi tropis sampai dengan badai dan angin topan. Topografi yang bergunung-gunung dan lembah dengan berbagai ngarai dan sungai berpotensi untuk mengalami banjir, longsor, dan erosi. Berdasarkan catatan kejadian bencana, daerah yang sangat rawan longsor adalah sepanjang pegunungan Bukit Barisan di Sumatera dan pegunungan di Jawa, Sulawesi, dan Nusa Tenggara (Kodoatie \& Roestam Sjarief, 2016).

Sekarang ini penduduk dunia menghadapi ketidakseimbangan ekosistem bumi yang menyebabkan kondisi meningkatnya suhu rata-rata global permukaan bumi akibat meningkatnya emisi Gas Rumah Kaca. Emisi Gas Rumah Kaca yang terdiri dari: karbondioksida, metana, dinitrooksida, hidrofluorokarbon, perfluorokarbon, dan sulfur heksafluorida di atmosfer yang dihasilkan terutama oleh pembakaran bahan bakar fosil (minyak bumi dan batu bara) serta penggundulan hutan dan pembakaran hutan.

Efek Rumah Kaca sebagai suatu bentuk sistem ekosistem di bumi justru sangat dibutuhkan oleh makhluk hidup di bumi, karena tanpa efek tersebut bumi akan menjadi lebih dingin. Akan tetapi, sistem tersebut akan bersifat merusak jika berlebihan dalam artian efek rumah kaca telah menghasilkan sejumlah panas yang berlebih dibandingkan dengan kondisi normalnya. Pemanasan global memicu terjadinya sejumlah konsekuensi yang merugikan baik terhadap lingkungan maupun setiap bidang kehidupan manusia. Beberapa di antaranya: naiknya permukaan air laut global disebabkan oleh mencairnya es di kutub utara dan selatan yang menyebabkan sejumlah pulau-pulau kecil tenggelam dan mengancam kehidupan sosial-ekonomi, meningkatnya intensitas fenomena cuaca yang ekstrim, punahnya berbagai jenis fauna, migrasi sejumlah hewan untuk menemukan habitat baru, meningkatnya frekuensi dan intensitas banjir, terjadinya perubahan arus laut, dan meluasnya berbagai penyakit tropis ke daerah-daerah baru. 
Pada intinya, pemanasan global memberikan nuansa baru yang mengerikan bagi kehidupan manusia di masa sekarang terlebih lagi untuk jangka waktu ke depannya bila tidak segera diatasi sedini mungkin. Oleh karena itu, walaupun boleh dikata sudah terlambat, sepatutnya kita membuat langkah-langkah strategis dalam mengatasi persoalan ini. Sementara itu, dari persoalan bencana alam yang selama ini terjadi kita belum bisa merumuskan dalam suatu manajemen bencana yang baku. Tulisan ini bermaksud untuk mengingatkan kembali akan potensi bencana yang ada di Indonesia, upaya pencegahan dan mitigasi, dan bagaimana model manajemen bencana berbasis pemberdayaan komunitas dalam menghadapi bencana dan isu pemanasan global. Frekuensi dan intensitas banjir akibat pemanasan global diprediksi terjadi 9 kali lebih besar, dimana 80\% terjadi di Asia Selatan dan Tenggara, maka kebutuhan untuk mengkajiulang (review) RTRWN menjadi semakin mendesak.

\section{METODE PENELITIAN}

Metode penelitian ini adalah penelitian kepustakaan (libraryresearch). Penelitian kepustakaan dilakukan dengan mengumpulkan berbagai sumber data relevan yang berasal dari sumber bacaan primer dan sekunder dari suatu topik permasalahan. Pada penelitian ini topik permasalahan yang dieksplorasi yaitu pengelolaan bencana berbasis pemberdayaan masyarakat.

\section{HASIL PENELITIAN DAN PEMBAHASAN}

\section{Potensi Bencana di Indonesia}

Potensi bencana yang ada di Indonesia dapat dikelompokkan menjadi 2 kelompok utama, yaitu potensi bahaya utama (main hazard) dan potensi bahaya ikutan (collateral hazard). Potensi bahaya utama ini dapat dilihat antara lain pada peta potensi bencana gempa di Indonesia yang menunjukkan bahwa Indonesia adalah wilayah dengan zona-zona gempa yang rawan, peta potensi bencana tanah longsor, peta potensi bencana letusan gunungapi, peta potensi bencana tsunami, peta potensi bencana banjir, dan lain-lain. Dari indikator-indikator tersebut dapat disimpulkan bahwa Indonesia memiliki potensi bahaya utama (main hazard potency) yang tinggi. Demikan pula dari indikator likuifaksi, bangunan yang terbuat dari kayu, kepadatan bangunan, dan kepadatan industri berbahaya maka potensi bahaya ikutan (collateral hazard potency) juga sangat tinggi. 
Potensi bencana akibat kenaikan permukaan laut terhadap kondisi lingkungan bio-geofisik yang berantai yaitu dengan meningkatnya frekuensi dan intensitas banjir maka terjadi perubahan arus laut dan meluasnya kerusakan mangrove, akibatnya akan meluas pula intrusi air laut yang mengancam kegiatan sosial-ekonomi masyarakat pesisir, serta berkurangnya luas daratan atau hilangnya pulau-pulau kecil. Saat ini terus terjadi penurunan luas hutan mangrove di Indonesia, dari 5.209 .543 ha (1982) menjadi 3.235.700 ha (1987) dan 2.496.185 ha (1993), sehingga dalam kurun waktu 10 th telah terjadi penurunan sekitar 50\% dari total semula. Akibatnya abrasi dan intrusi air laut tak terelakkan dipicu terjadinya land subsidence akibat penurapan air tanah yang berlebihan, di Jakarta diperkirakan pada periode 2050-2070 intrusi air laut akan mencakup 50\% dari luas Jakarta Utara. Gangguan terhadap kondisi sosial-ekonomi masyarakat di antaranya hilangnya lahan budidaya pertanian di sepanjang dataran pantai, gangguan jaringan jalan lintas dan kereta api di Pantura Jawa dan Timur-Selatan Sumatera, genangan terhadap permukiman kota-kota pesisir di Pantura Jawa, Sumatera bagian timur, Kalimantan bagian selatan, Sulawesi bagian barat daya, dan beberapa bagian Papua. Berkurangnya luasan kawasan pesisir dan bahkan hilangnya pulau-pulau kecil yang mencapai angka 2000-4000 pulau, tergantung dari kenaikan muka air laut yang terjadi. Dengan asumsi kemunduran garis pantai sejauh $25 \mathrm{~m}$, pada akhir abad 21 lahan pesisir akan hilang hingga 202.500 ha.

\section{Pengelolaan Bencana Berbasis Pemberdayaan Masyarakat}

Sebagai wilayah yang sangat rawan bencana, upaya strategis untuk melindungi setiap warga negara dengan langkah-langkah penanggulangan bencana (manajemen bencana) baik sebelum, pada saat dan setelab bencana terjadi menjadi penting untuk dilakukan. Manajemen bencana merupakan seluruh kegiatan yang meliputi aspek perencanaan dan penanggulangan bencana, sebelum, pada saat dan sesudah terjadi bencana yang dikenal sebagai Siklus Manajemen Bencana (seperti terlihat dalam Gambar Siklus Manajemen Bencana, gambar. 1), yang bertujuan untuk: (1) mencegah kehilangan jiwa; (2) mengurangi penderitaan manusia; (3) memberi informasi masyarakat dan pihak berwenang mengenai risiko, serta (4) mengurangi kerusakan infrastruktur utama, harta benda dan kehilangan sumber ekonomis. 


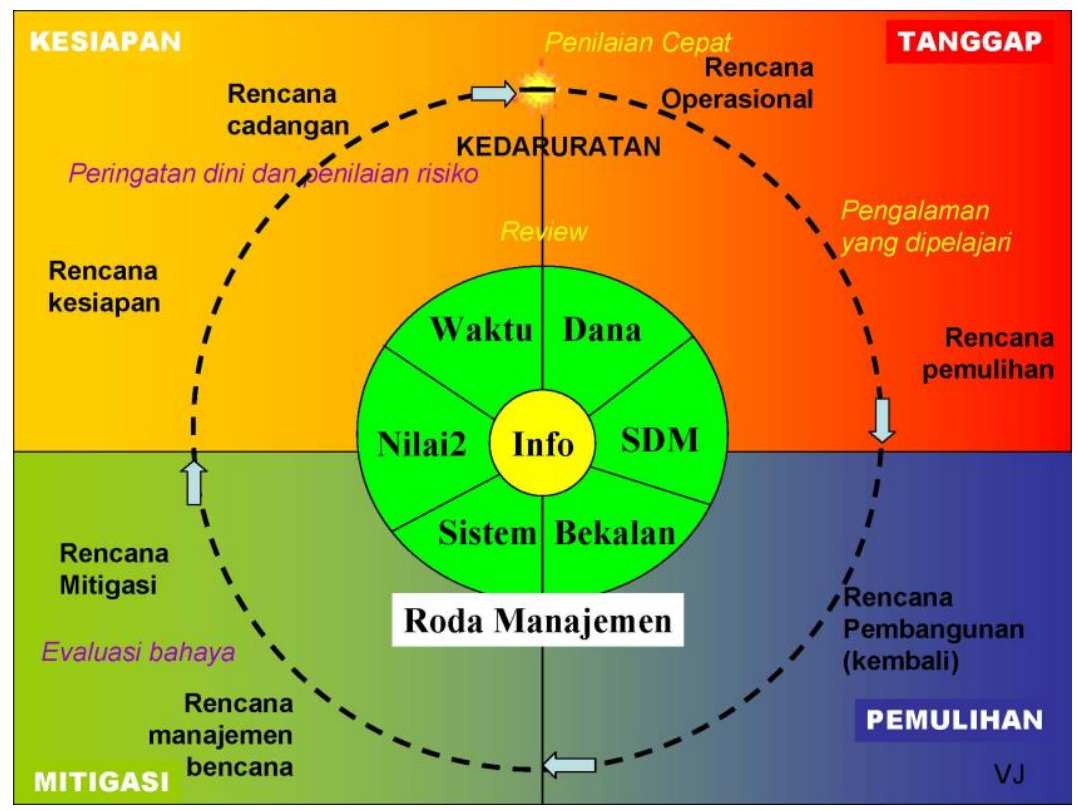

Gambar.1. Siklus Pengelolaan Bencana

Secara umum kegiatan manajemen bencana dapat dibagi dalam kedalam tiga kegiatan utama, yaitu:

1. Kegiatan pra bencana yang mencakup kegiatan pencegahan, mitigasi, kesiapsiagaan, serta peringatan dini;

2. Kegiatan saat terjadi bencana yang mencakup kegiatan tanggap darurat untuk meringankan penderitaan sementara, seperti kegiatan search and rescue (SAR), bantuan darurat dan pengungsian;

3. Kegiatan pasca bencana yang mencakup kegiatan pemulihan, rehabilitasi, dan rekonstruksi.

Kegiatan pada tahap pra bencana ini selama ini banyak dilupakan, padahal justru kegiatan pada tahap pra bencana ini sangatlah penting karena apa yang sudah dipersiapkan pada tahap ini merupakan modal dalam menghadapi bencana dan pasca bencana. Sedikit sekali pemerintah bersama masyarakat maupun swasta memikirkan tentang langkah-langkah atau kegiatan-kegiatan apa yang perlu dilakukan didalam menghadapi bencana atau bagaimana memperkecil dampak bencana.

Kegiatan saat terjadi bencana yang dilakukan segera pada saat kejadian bencana, untuk menanggulangi dampak yang ditimbulkan, terutama berupa penyelamatan korban dan harta benda, evakuasi dan pengungsian, akan mendapatkan perhatian penuh baik dari pemerintah bersama swasta maupun 
masyarakatnya. Pada saat terjadinya bencana biasanya begitu banyak pihak yang menaruh perhatian dan mengulurkan tangan memberikan bantuan tenaga, moril maupun material. Banyaknya bantuan yang datang sebenarnya merupakan sebuah keuntungan yang harus dikelola dengan baik, agar setiap bantuan yang masuk dapat tepat guna, tepat sasaran, tepat manfaat, dan terjadi efisiensi.

Kegiatan pada tahap pasca bencana, terjadi proses perbaikan kondisi masyarakat yang terkena bencana, dengan memfungsikan kembali prasarana dan sarana pada keadaan semula. Pada tahap ini yang perlu diperhatikan adalah bahwa rehabilitasi dan rekonstruksi yang akan dilaksanakan harus memenuhi kaidah-kaidah kebencanaan serta tidak hanya melakukan rehabilitasi fisik saja, tetapi juga perlu diperhatikan juga rehabilitasi psikis yang terjadi seperti ketakutan, trauma atau depresi.

Di dalam perpektif lingkungan fisik, kesiapan menghadapi kejadian bencana meliputi prediksi kejadian bencana (pemantauan bencana), kesiapsiagaan emergensi (persiapan tanda-tanda bahaya, sistem peringatan dini, dan sistem evakuasi), dan sosialisasi bencana melalui media cetak maupun ceramah. Pada saat/sesaat setelah kejadian bencana dengan penyelamatan korban bencana, termasuk pula usaha pencarian dan evakuasi (pengungsian) korban, pemberian bantuan kepada korban meliputi pemberian bantuan bahan makanan, pelayanan sosial (santunan) dan pelayanan medik. Pasca kejadian bencana dengan rehabilitasi lahan bencana terutama pada lokasi-lokasi bekas pemukiman penduduk yang rusak atau bahkan hancur akibat bencana, rekonstruksi atau pembangunan dan penataan kembali lahan bencana.

Dalam beberapa tahun terakhir pengelolaan bencana bergeser ke arah pemberdayaan komunitas, seperti yang dikemukakan dalam World Conference on Natural Disaster Reduction di Yokohama pada tahun 1994 mengenai Community-based Disaster Management. Suatu kesadaran mengenai pentingnya upaya pemberdayaaan komunitas agar memiliki informasi memadai, waspada, lebih aktif, serta memiliki kemampuan untuk berkoordinasi dan mendukung pemerintah dalam kegiatan prevensi maupun mitigasi. Penanganan bencana membutuhkan kecepatan, serta pendekatan berdasarkan kekhasan masalah di lapangan, yang sangat terbantu jika keterlibatan komunitas tinggi. Komunitas lokal dapat memberikan dukungan dalam bentuk informasi, usulan maupun gagasan kepada pemerintah, bahkan sumber daya tertentu yang tidak dapat disediakan oleh pemerintah. 
Melibatkan komunitas dalam perencanaan manajemen bencana dan mendorong komunitas berpartisipasi akan memberikan nilai tambah. Demikian juga pada saat pemulihan pasca bencana, pengembangan komunitas merupakan prioritas, yang melibatkan langkah-langkah konsultatif dengan komunitas, penerapan prinsip "dari komunitas untuk komunitas" dalam pemanfaatan sumber daya, serta timbulnya kemitraan jangka panjang dengan komunitas. Keterlibatan terhadap komunitas memiliki jangkauan yang luas sehingga seluruh aktivitas berdasarkan konsultasi dan usulan-usulan dari komunitas, memantau kebutuhan yang nyata, serta memodifikasi dukungan strategis untuk menjaga keterkaitannya dengan situasi yang berkembang (Irwan Abdullah, 2008).

Manajemen bencana haruslah mempertimbangkan dan responsif terhadap keberagaman, perbedaan, dan persaingan yang dapat saja timbul karena faktor sosial, ekonomi, kepentingan politik, perbedaan komunitas, bahkan mungkin pula agama. Perbedaan ini acap menghasilkan suatu hubungan yang kompleks dan dinamis. Penanganan yang salah dapat menimbulkan konflik horisontal, yang sangat tidak diinginkan. Juga harus memahami dengan hati-hati kemungkinan terjadinya konflik yang mungkin timbul sebagai akibat perbedaan kelompok maupun perbedaan kebutuhan. Sehingga hubungan yang terbangun dengan komunitas harus memberi masukan mengenai prioritas-prioritas tindakan dalam penanganan bencana, menyeimbangkan dan memperantarai agar terjadi titik temu yang paling dapat diterima dalam kondisi setempat. Pendekatan berbasis komunitas ini pula yang perlu menjadi perhatian kalangan bisnis dalam melaksanakan Corporate Sosial Responsibility (CSR), dalam menyalurkan dananya. Juga bagi perusahaan yang mempunyai program community development.

Upaya pemberdayaan masyarakat terkait dampak pemanasan global diprioritaskan pada kawasan lindung bagian hulu, khususnya hutan tropis, daerah sempadan pantai, sempadan sungai, mangrove, terumbu karang, suaka margasatwa/cagar alam/habitat flora-fauna, dan kawasan-kawasan yang sensitif secara ekologis atau memiliki kerentanan tinggi terhadap perubahan alam atau kawasan yang bermasalah. Dalam rangka kebijakan penataan ruang, maka RTRWN merupakan salah satu instrumen kebijakan yang dapat dimanfaatkan untuk dampak pemanasan global terhadap kawasan pesisir dan pulau-pulau kecil. Revitalisasi dan operasionalisasi rencana tata ruang yang berorientasi kepada pemanfaatan dan pengendalian pemanfaatan ruang kawasan pesisir dan pulau-pulau kecil dengan tingkat kedalaman yang 
lebih rinci sangat diperlukan. Peran geograf tentunya menjadi sangat besar dalam menyediakan data sistem informasi atau data base berupa peta-peta yang dapat digunakan mewujudkan keterpaduan pengelolaan kawasan pesisir dan pulau-pulau kecil sekaligus menghindari terjadinya konflik lintas batas.

\section{DAFTAR PUSTAKA}

Djoko Kirmanto. (2020). Lokakarya Penataan Ruang Sebagai Wahana untuk Meminimalkan Potensi Kejadian Bencana Longsor, Jakarta 7 Maret 2006.

Irwan Abdullah. (2016). Konstruksi dan Reproduksi Sosial atas Bencana Alam, Working papers in Interdisciplinary Studies No.1 Januari 2008, Yogyakarta: Sekolah Pascasarjana UGM.

Kodoatie, R.J. dan Roestam Sjarief. (2016). Pengelolaan Bencana Terpadu, Jakarta: Penerbit Yarsif Watampone.

Sutikno. (2008). Geografi dan Kompetensinya dalam Kajian Geografi Fisik, Materi Sarasehan Keilmuan Geografi, 18-19 Januari 2018, Yogyakarta: Fakultas Geografi UGM.

Undang-undang Republik Indonesia No.24 Tahun 2017 tentang Penanggulangan Bencana, Jakarta: Badan Koordinasi Nasional Penanganan Bencana (BAKORNAS PB).

bttp:/ / independen69.wordpress.com/2017/12/03/pemanasan-global-global-warming/ $10 / 28 / 2018$. 